\title{
Learning from the Germans? History and Memory in German and European Projects of Integration ${ }^{1}$
}

\author{
Andrew H. Beattie, University of Technology, Sydney
}

In recent years, discussion of European cultural values has increasingly included the proposition that 'Europe' needs to face up to its difficult past(s). For European projects of cooperation and integration considerable significance is now attributed to history and memory. This is a historical novelty. The determination to avoid another war among European nations has long been central to the master narrative of European integration. Yet at least until the 1980s, 'Europe' in the sense of the European Economic Community and the European Community (EC) was a purely economic, legal-political entity. It had few shared values and symbols, and certainly was not a community of memory. As Tony Judt $(2000,293)$ argues, both western integration and that pursued under Soviet hegemony in Eastern Europe were characterised by 'the erection of an unnatural and unsustainable frontier between past and present in European public memory' (or better, in European public memories). Shared memories in the west were limited to the integration process itself and did not reach back beyond 1945, apart from the resolve of 'never again.' A focus on the future rather than the past had also characterised older concepts of European integration (Speth 1999, 169).

\footnotetext{
${ }^{1}$ This article began as a paper presented at a September 2005 workshop of the 'Competing Euro Visions' project at the Institute for International Studies, University of Technology, Sydney, and benefited subsequently from the author's participation in Bo Stråth's seminar 'Historical writing and politics of remembrance' at the European University Institute, Florence, in 2006-7. It is a slightly revised English language version of a chapter, 'Geschichte und Erinnerung in deutschen und europäischen Einigungsdiskursen,' in 'Schmerzliche Erfahrungen' der Vergangenheit und der Prozess der Konstitutionalisierung Europas, edited by C. Joerges, M. Mahlmann and U. K. Preuß (forthcoming 2007). The author gratefully acknowledges the publisher, Verlag für Sozialwissenschaften, for permission to publish this English-language version.
} 
Direct concern with the past increased only in the last two decades. The promotion of a shared historical consciousness became part of a larger attempt to imbue the dry bureaucratic and economic process of European integration with a common identity. Since the 1980s, discussions of 'European values' have frequently, but by no means exclusively, addressed the legacy of twentieth-century warfare and genocide in Europe (Speth 1999; Rousso 2004). This trend accelerated with the prospect and, since 2004, the advent, of the accession to the European Union (EU) of former members of the Soviet bloc in Eastern Europe (Thum 2004, 7; Gellner and Glatzmeier 2005, 11). Of course, one should not fall into the trap of equating Europe with the EU. The larger and looser Council of Europe also promotes joint projects for the teaching of history at schools and commemoration of the Holocaust. ${ }^{2}$ Such enterprises are inseparable from the spread of 'cosmopolitan memory' of the Holocaust throughout the Americanised world (Levy and Sznaider 2002).

The EU 'Treaty Establishing a Constitution for Europe' takes the effort to anchor the integration process in a common understanding of history to a new level. References in the constitution's preamble to Europe being 'reunited after bitter experiences' and to the European peoples' determination 'to transcend their former divisions' indicate this new, official prominence (European Union 2004). Awareness of, and (more or less selfconscious) confrontation with the painful past are apparently to function as a driving force of the integration project in the present and future. As Christian Joerges (2005, 248) has pointed out with understatement, it is possible to imagine a more substantial formulation than the preamble provides. It remains unclear which bitter experiences are meant, how Europe's citizens intend to transcend their previous divisions, and how and when Europe managed to reunite itself. Lack of specificity is hardly unusual in such a context. However, as Murray Pratt $(2005,7)$ argues, it remains characteristic of the circular, unreflective moment of EU perpetual self-constitution. There is much to be said for Pratt's suggestion that the past division in mind is not an internal one, but the foundational severing of the chosen 'Europa' from her southern and eastern neighbours and subsequent others $(2005,15)$.

\footnotetext{
${ }^{2}$ See the projects of the General Directorate IV for Education, Culture and Heritage, Youth and Sport (Council of Europe 2007a and 2007b; Domnitz 2007).
} 
The premise of this article, however, is that historical divisions and experiences within Europe lie at the heart of attempts to forge a common European memory in support of integration. The history of the Cold War and the continent's division into East and West are of particular importance, as is suggested not least by the fact that the preamble's reference to the bitter past was a Polish initiative (Joerges 2005, 248). As important as the Holocaust and (post-)colonialism and their consequences are (Müller 2007), the continent's real and imagined east-west division should not be neglected. Memory of the latter, as well as being intimately connected to that of the Holocaust, is important in its own right, but often receives less scholarly attention, particularly in the Anglophone world.

This article considers whether and how German efforts to create a shared, national history and public memory after unification in 1990 can inform the European discussion. The union of the western Federal Republic of Germany (FRG) and the eastern German Democratic Republic (GDR) has often been cast as a small-scale experiment of the integration of western and eastern Europe, or more specifically of the EU's eastward expansion. In economics and migration studies, for example, 'lessons' for Europe have been sought from German experiences, often with a view to avoiding the problems of the German case (Sinn 2000; Hochberg 1998). In contrast, German experiences with confronting difficult twentieth-century pasts are on the whole viewed positively. Indeed, recent commentators have suggested that German handling of the 'double' totalitarian past could be instructive and even exemplary for Europe (Troebst 2006, 26; Faulenbach 2006, 248-49).

In this article, I explore, critically, what lessons, if any, German experiences might in fact hold for 'Europe.' In the German context, discussions of public memory focussed on two related goals: on the one hand, the achievement of a unified public memory of National Socialism and Communism, and, on the other, the development of a common history of the divided postwar era. Both tasks were pursued most energetically, prominently and directly, by two Commissions of Inquiry of the German Federal Parliament between 1992 and 1998 (Deutscher Bundestag 1995 and 1999), which were the subject of the author's doctoral thesis (Beattie 2005a). This provides the major empirical source for the present article's discussion of German experiences, although I also draw more generally on German commemorative politics in the first decade after 
unification, and contrast this with often more sophisticated historiography. The primary purpose of this paper is not to analyse the German case per se, but to question assumptions about its exemplary status for European projects and to consider its relevance to those projects. ${ }^{3}$ The second section addresses the treatment of the EastWest division during the Cold War, while debates about totalitarianism and the relationship between National Socialism and Communism in public memory are the subject of the third and final part. In both sections, European parallels with, and possible 'lessons' from the German experiences are discussed, using examples from recent 'European' public memory debates and initiatives and historiography on the one hand, and the author's own research and the growing secondary literature on Germany on the other. First, however, it is necessary to consider the comparability of the two contexts, and thus the limiting preconditions for any German lessons for Europe.

\section{Differing Starting Points and Similar Goals}

Parallels between German unification and European integration and expansion are problematic, as there are considerable differences in the character of the processes, with implications for history and public memory. The opening of the German-German border in November 1989 caught the political establishments and publics on both sides by surprise. The remarkable speed of the subsequent 'rush to German unity' (Jarausch 1994), formalised in October 1990, resulted not least from the assumption of continuing German ethno-national identity and indeed homogeneity, despite forty years of division. The process was frequently (and not least by the western politicians who drove the constitutional process) conceived as reunification, as the restoration of 'normal' nationstatehood (Zens 2000). The insight that forty years of divergent socialisation had had enduring effects on East and West Germans, and the desire to purge them (mainly on the eastern side) in the name of 'inner unity' were later developments. Indeed, the project of a common history arose only in the years following formal unification. In the course of difficult ongoing integration, it was nevertheless viewed as an unproblematic and readily attainable goal (Wüstenberg 2004; Beattie 2005a). As much as the enlarged Federal Republic after 1990 differed from previous incarnations of German nation-,

\footnotetext{
${ }^{3}$ A detailed treatment of the positions of various political camps is impossible within the scope of this article, which concentrates on the dominant views of Christian Democrats and Free Democrats who were in government from 1990 until 1998. Their positions on various issues were shared or rejected by Social Democrats and Greens, and rejected in total by the post-communist Party of Democratic Socialism (PDS). See Beattie (2005b) for a brief analysis and Beattie (2005a) for a more comprehensive one.
} 
state-, or nation-state-hood, the parameters of German history appeared to be clearly defined, and recourse could be taken to extant understandings of national history and practices of public memory. ${ }^{4}$

Despite the loose talk in the Constitutional Treaty preamble of Europe being 'reunited,' European integration is conceived rather differently, not least where history and memory are concerned. As Judt (2005, 303, 308-9) argues, the beginnings of western European integration lay in quite traditional inter-state instruments and appeared only in retrospect as a revolutionary attempt at supranational integration. Yet long before the collapse of the Soviet bloc it had become clear that with the EC a qualitative novelty had come into existence and continued to constitute itself. With eastern expansion since 2004, any remaining doubts about the constructed-ness of the union have disappeared, and post-entry integration is expected to remain a long-term project. This applies all the more to the project of a common history and memory, which, in contrast with the German case, is being pursued contemporaneously with economic, legal, social and political integration and expansion. Every plan for a shared European understanding of the past assumes the difficulty of overcoming inherited, primarily national, approaches to history (Pavković 2000). Both the 'Europe' of the Council of Europe and that of the European Union lack the definitional clarity and ready-made public memories of the German case. Where do (or should) the temporal and geographical borders of European history lie? What is to be understood as 'European,' and what as regional, national, global or (post-)colonial (Monteath 1999; Jarausch and Lindenberger 2007)? Such European problems of definition played little roles in the German case, although many of them arguably also applied, mutatis mutandis.

Both the constructed and the processual nature of the European case appear to offer hope for more multiple perspectives and critical reflection than characterised the German example. During German unification, at most superficial differences between East and West were anticipated and a homogenous, indeed almost uniform, understanding of history was, and for years continued to be, desired. In contrast, European discourses assume considerable heterogeneity. For all the appeals to unity, the attractiveness and necessity of diversity are upheld. The expectations and hopes in both

\footnotetext{
${ }^{4}$ The preamble to the unification treaty between East and West Germany spoke of "consciousness of the continuity of German history' (Bewußtsein der Kontinuität deutscher Geschichte) (Vertrag 1990).
} 
cases thus indicate the enduring significance of national identifications, albeit with contrasting consequences on the two levels.

Further differences concern the pasts in question. There was no debate about colonialism in the German case, whereas it is, and must be, of greater significance for Europe as a whole. ${ }^{5}$ On the other hand, the German relationship with National Socialism, the Second World War and the Holocaust is necessarily different from any general European relationship, even if no European country can (or does) removes itself completely from discussions about complicity in the Holocaust and co-responsibility for, and accommodation with, dictatorships and occupation regimes. The German experience of the Cold War East-West division also differs from that of Europe in significant ways.

Despite such differences, shared understandings of the past feature in both cases simultaneously as the prerequisite for, and the outcome of, further integration of the expanded community. ${ }^{6}$ Although varying degrees of anticipated and desired conformity and plurality are in evidence, and although the debate about memory commences at different phases of the integration processes, the dominant discourse in both cases holds that transcending 'divided memory' is necessary to overcome past and present cleavages and tensions, and to realise common visions of the future. Moreover, there are similarities in the imbalances of symbolic and intellectual capital. German unification was constitutionally, administratively and, to a considerable extent, intellectually accomplished as the accession of the eastern 'new federal states' to the Federal Republic. The balance of power was unmistakable, and not unlike that which characterises the accession to the EU club of the 'new member states.' The following sections demonstrate that, in accordance with this deeply asymmetrical unification

\footnotetext{
${ }^{5}$ In recent years the colonial past has received more attention in Germany, but it was almost completely absent before the late 1990s.

${ }^{6}$ It is worth casting a second glance at the implications of the different phases of the integration processes during which the goal of a shared understanding of the past gained prominence. Above I suggested that the pursuit of a common memory as a component of the ongoing broader integration process in the European case represents a possible gain in terms of critical reflection and multiple perspectives. Yet if consenting to a particular 'memory regime' (Langenbacher 2003) constitutes an 'entry ticket' to the union (Judt 2005, 803), or, conversely, if divergence from the dominant partner's memory regime represents a co-hindrance to entry, as in the case of Turkey and the EU, then the sequence of the German case-with the memory debate beginning only after formal political accession - appears more conducive to plurality and to agency on the part of the 'minor' party. In short, apologists for Communist rule in East Germany were not excluded from unification, but attacked and marginalised afterwards.
} 
process, the course and outcome of public memory debates were characterised by varying degrees of inconsistency and hypocrisy, success and failure.

\section{Overcoming Cold War Divisions}

In Germany after 1990, the development of a common memory of the divided past was granted considerable significance for the 'inner unity' of the recently unified country. Politicians from various parties were disturbed by the apparently increasing alienation of easterners and westerners. In order to overcome the 'Wall-in-the-head' syndrome and the 'crisis of unification' (Kocka 1995), they argued, the Germans needed to listen to each others' stories and to embrace the divided past. Politicians and allied historiansprimarily but by no means only from the political right — demanded a historically-rooted national identity, and sought to have the postwar era understood as a history of national suffering caused by Communist crimes, but also of eventual redemption through unification (Beattie 2005b; Zens 2000). History's 're-nationalisation' was thus to legitimise reunification and support integration (Jarausch 1995). Both historical scholarship and public memory were to praise those Germans who had held firm to their desire for national unity and to scorn those who had made themselves comfortable in national division or, worse still, embraced post-national values. In and beyond the Commissions of Inquiry, such criticism was directed at eastern dissidents who had still hoped for an independent East German state in 1989-1990. Above all, however, it targeted westerners, many of whom had become increasingly indifferent to, and ignorant of, the GDR. Some had come to equate the Federal Republic with 'Germany,' a tendency that culminated in GDR citizens who crossed the border following the breaching of the Berlin Wall being met with such greetings as 'Welcome to Germany' (Bender 2000; Beattie 2005a).

In reunified Germany easterners and westerners were now supposed to regard the history of the other German state as an integral component of their own history. Only then, it was suggested, would inner unity be achieved. This ambitious goal met with only moderate success, despite repeated exhortations to come together by listening to one another's histories. Even the Commissions of Inquiry made little effort to convince westerners to accept the GDR past as a component of their own history. They held numerous public hearings and commemoration ceremonies in eastern cities, but in the west only in the parliamentary building in Bonn (Beattie 2005a). Westerners were 
hardly addressed, with the exception of parts of the western political class on particular topics, on which more below.

The west was also neglected in terms of content, and an opportunity thus went begging for easterners to learn more about the history of the Federal Republic or for the development of a shared history of division. Revealingly, it was often precisely those opinion makers who pointed most vociferously to the need for a unified understanding of the divided past who simultaneously extracted the Federal Republic from the analysis, or who rejected out of hand even the mildest criticism of its history (and castigated its critics for obscuring the fundamental distinction between democracy and dictatorship). Exempting the western past from examination did not prevent conservatives from implicitly or explicitly assessing the East German past against western norms or from making occasional politically expedient comparisons. When the west was examined, then generally it was in direct connection with the GDR, whether in the form of western parties' policies towards East Germany and the national question, the East German regime's efforts at infiltration and propaganda in the west, or the population's attitudes to the German question and to the GDR. Such issues offered western conservatives and eastern dissidents the opportunity to castigate the western Left not just for its national indifference, but for having played down the GDR's democratic illegitimacy and human rights abuses (Beattie 2007). Otherwise, the Federal Republic featured as a self-evident, natural success story, without conflicts, contradictions or ruptures (Beattie 2005a).

In stark contrast, almost every aspect of the history of the East German regime was critically examined. The Commissions of Inquiry sought and found not only their main audience but also their historical subject matter in the East. The development of a common German history of division was thus predicated on a critical reappraisal, indeed the delegitimisation, of the East German past. The prevalent narrative of GDR history was dominated by the rise and fall of totalitarian, Communist tyranny, and thus by repression and resistance. Society and everyday life came into view only as far as they provided examples of repression or resistance. The East German state was denied any legitimacy, and even its anti-fascist doctrine was depicted as a deceptive, hypocritical instrument for justifying Communist dictatorship (Beattie 2005a). Easterners thus were not only supposed to internalise uncritically the history of the 
Federal Republic (apparently through osmosis), but were also to accept this polarised, bleak image of their former state. Whoever pointed to any positive aspects to life in the GDR ran the risk of being branded an undemocratic apologist for Stalinism or a nostalgic irredentist. Even the heritage of the East German opposition and the 'peaceful revolution' of 1989 — which eastern and western anti-Communists often invoked as the only positive eastern contribution to the unified country-remained marginal in national commemorative activity, as suggested by the absence until the eleventh hour of an eastern representative in plans to celebrate the tenth anniversary of unification. ${ }^{7}$ The crude division of the eastern and western pasts into black and white respectively reflected the wider balance of power of reunification, and could do little to contribute to integration. On the contrary, it contributed to widespread impressions of western 'colonisation' und 'victor's justice,' however one-sided and misleading such notions were (Beattie 2005a).

This rough, but by no means inaccurate, sketch of the dominant post-unification treatment of Germany's postwar history applies to public memory until at least the late 1990s. Clearly, similar treatment would hardly be advisable for Europe. Scholarly research, however, assumed more moderate and subtle approaches from the mid-1990s, even if it shared (and in part continues to share) some of the same tendencies. During the era of division, Communism had been largely written out of German history in the west, all the better to condemn the GDR as an illegitimate Soviet import without German roots. The presence of German Communists in the western occupation zones after the war and in western state parliaments into the 1950s was largely forgotten. Since unification, much has been written about the GDR's fixation on its larger, more prosperous western rival, but the formative role played by the eastern 'ever present other' (Weitz 2001) in West Germany's political, economic, social and cultural development is only slowly being addressed (Kleßmann 2001; Faulenbach 1999). All too often, the GDR has been cast merely as an unfortunate failure that was doomed from the start, the shadow to the sunny side of the Federal Republic's success story, while the latter can, it seems, still be told with few if any references to the former (Schildt 1999; Jarausch 2004a). Historians who seek to do justice to the double past by noting conceptual complexities, such as the 'asymmetrically interconnected parallel history,'

\footnotetext{
${ }^{7}$ On this point compare McAdams $(1997,307)$ with Meckel (2001).
} 
have remained a minority. ${ }^{8}$ Even if their scholarly influence is considerable, the impact they have on public memory is surely limited. Without expecting the same degree of sophistication from public memory as from scholarship, such perspectives would most likely have been more conducive to integration than the dominant black-and-white images that reflected and legitimised the fundamental asymmetries of unification.

European public memory of the East-West division could profit from considering not just the best scholarship on that history, but also the German precedent. The asymmetrical relationships and conceptual difficulties of German debates about postwar division have numerous European parallels. As in the German case, the East needs to be incorporated into a self-satisfied western narrative that takes the western part for the whole and treats its history as an unproblematic success story of ever increasing prosperity and integration. In both cases the contingency and historicity of the EastWest border is often forgotten. Gregor Thum $(2004,4-5)$ has pointed convincingly to the need to address 'blank spots in the history of European integration' in relation to eastern Europe. Prominent among these are the frequent equation of western Europe, or indeed the EU, with Europe per se, and the erroneous notion of central and eastern European countries' 'return to Europe' since 1989, as though they had somehow left the continent (Gerner 1999). Crucial to a more inclusive history and conceptualisation of European integration, according to Thum (2004), is the recognition, first, that eastern Europe and Europeans were central to pre-Cold War notions of Europe and European integration and, secondly, that post-1945 western integration was possible and necessary precisely because of the continent's division. Westerners' failure to recognise that their freedom, prosperity and integration came at the expense of eastern Europe's forced integration under Soviet rule (Judt 2005, 242, 303-4) is a continuing source of bitterness for many easterners. This was demonstrated by the President of the Republic of Latvia, Dr Vaira Vike-Freiberga (2005), in advance of the celebrations to mark the sixtieth anniversary of the end of World War Two in Europe. The ubiquitous notion of 'liberation' in 1945 was, and remains, problematic and controversial in eastern Europe (including East Germany), a fact that must be considered in narratives of European

\footnotetext{
${ }^{8}$ Asymmetrisch verflochtene Parallelgeschichte (Kleßmann 1993; Bauerkämper et al., 1998; Niethammer 1999; Faulenbach 1999; Kleßmann 2005).
} 
history. ${ }^{9}$ The self-satisfied and myopic slogan of the European Union (2007a) for the celebration of the fiftieth anniversary of the Treaty of Rome- 'Together since 1957' suggests that more critical reflection is required in this regard. ${ }^{10}$

Both contexts display insufficient readiness to differentiate within the relevant 'East.' Popular generalisations about easterners (and westerners) were counterproductive in Germany, and the East-West dichotomy served to obscure vital distinctions among representatives, supporters, critics, victims and opponents of the East German regime. Evaluations of the GDR were determined more by ideological and political beliefs than by geography, and there were both 'winners' and 'losers' with the end of the Cold War and unification. ${ }^{11}$ This also applies to eastern Europe. It is important, as Judt (2000, $307 ; 2005,202)$ stresses, to consider divergent experiences, attitudes and memories within eastern European countries, as well as those between them (Troebst 2006). The historical activities of the Council of Europe suggest such awareness and a degree of openness to multiple perspectives, although pluralism is frequently conceived in ethnonational rather than ideological terms (Stradling 2003).

The ideological blinkeredness of much public memory and some scholarship in Germany also has European equivalents. In scholarly and public depictions of eastern European history or histories, one often finds the familiar reduction of the past to that of the rule and crimes of the totalitarian party-state. Complex histories are reduced to a 'Black Book' (Courtois et al., 1999). Simple dichotomies between democracy and dictatorship abound. Where, for example, western European school history textbooks move beyond the absolute dichotomies of the Cold War conflict between the superpowers, they perhaps mention perestroika, while many texts in post-Communist states simply externalise and demonise Communism, which appears exclusively as a Soviet imposition without any indigenous roots. The 'end of History' seems to have

\footnotetext{
${ }^{9}$ German proponents of the totalitarian paradigm also stress that only the western part of the country was liberated in 1945 (Möller 1995; Knabe 2005). The notion of liberation has more complex implications in Germany than in countries occupied by the Nazis, being potentially either self-exculpatory or, when contrasted with the notion of defeat, more critical (Frei 2005).

${ }^{10}$ The German language version of the website of the European Union (2007b) provides an excellent example of the equation of the EU with Europe, stating - where other languages merely call for 'Europe' to be celebrated - that 'Europa is having its birthday' (Europa hat Geburtstag).

${ }^{11}$ The superimposition of the East-West issue was not least the result of PDS efforts to redefine itself as a, indeed the only, eastern party, and to depict critical views of the East German past as emanating from the West (Oswald 2004; Beattie 2005a).
} 
made substantial discussion of socialism, Marxism, Leninism, Communism or capitalism virtually redundant for European history textbooks, and society and the social question are largely ignored (Pingel 2000). ${ }^{12}$ How people lived under Communist regimes is not explored, and neither is how they received and responded to official ideological dictates, for example in the realm of public memory (Karge N.d).

Differentiated and nuanced depictions are rare, and the historicisation of Communism appears to be more advanced in Germany than further east (Kolář 2006; Pingel 2000, $45)$.

It remains difficult to assess whether rather diffuse European public memory regarding the history of the Cold War resembles or avoids the extremes of the rigorous antiCommunism found in Germany and numerous eastern European countries. A resolution of the Parliamentary Assembly of the Council of Europe (2006) on the 'Need for international condemnation of crimes of totalitarian Communist regimes,' employs a familiar uncompromising vocabulary. The resolution provides an unspecific catalogue of Communist crimes, and yet it also acknowledges that Communist Parties have made (similarly unspecified) contributions to democracy. The resolution could hardly be said to contribute to a complex understanding of the past, even if it has symbolic value in indicating that Communist crimes have not been forgotten.

There is perhaps even less awareness at European level than there was in Germany that Cold War ideological conflicts also ran through western societies and that at the end of the conflict there were, therefore, also 'losers' in the west. Although The Black Book of Communism (Courtois et al. 1999) is rightly interpreted not least as a criticism of the western European Left, Communism in the west is barely mentioned in discussions about developing a common European memory (Rousso 2004, 1; Morgan N.d.). As in Germany, the issue is often treated as one that only concerns the East. A European discussion of Communism in the west would most likely be more productive and less ideologically confrontational than the German debates, which in large part remained at the level of a highly moralised (neo-)conservative reckoning with the western Left. After all, the histories of Communist Parties in France and Italy are significantly

\footnotetext{
${ }^{12}$ Here the intensity of German attention to the East German past in school and university curricula and texts is rather atypical, although the GDR boom of the early and mid 1990s died down by the end of the decade (Pasternack 2001; Hüttmann 2004; Arnswald 2004).
} 
different from the smaller and more marginal Communist Party of Germany (KPD) of the first postwar decade, or from the German Communist Party (DKP) of the 1970s, and are hardly reducible to their manipulation by Moscow (or East Berlin). Genuinely transnational perspectives on interactions and permeations across the Iron Curtain (or within the Soviet bloc) appear to be similarly necessary and difficult to achieve as their German equivalents, even if the roll of eastern Europe or Russia as the 'Other' in the construction of (western) Europe is already better understood than its German-German counterpart (Karge N.d). A shared memory of Europe's divided Cold War past that does justice not only to manifold historical complexities and interactions but also to divergent contemporary perspectives is hardly in sight. If indeed the pursuit of that goal is deemed necessary, it could benefit both from considerable achievements in the fields of German and European historical scholarship, as well as from the significant failures of German public memory after unification.

\section{A European 'Historians’ Dispute’?}

The notion of the usefulness for 'Europe' of German experiences in dealing with complicated pasts refers generally to the handling of the 'double' totalitarian past of Nazism and Communism, rather than that of the double postwar past of democracy and dictatorship. The foregoing discussion of the modalities of the latter is nevertheless necessary not only because of the obvious, if often overlooked, parallels between the German and European division into East and West, but also because the treatment of Nazism and Communism cannot be understood without it. The debate about the two totalitarianisms required the demonisation of the GDR, as discussed above, while the black-and-white approach to the two postwar states played a significant role in attitudes to the public memory of National Socialism in postwar and post-unification Germany. There is much to be said for a generally positive assessment of the German handling of the double past of Nazism and Communism, especially in comparison with contrasting examples from some eastern European countries (Judt 2005, 824-29). Yet a degree of caution is necessary. Jan-Werner Müller (2007) rightly questions the suitability of the German model of 'coming to terms with the past' (Vergangenheitsbewältigung) for European export. Indeed, whether it can be characterised as a model is also open to question. 
The postulated exemplary character of German public debates about the double past for Europe rests, in part, on their misrepresentation or misunderstanding. It is often assumed that the 1990s saw the relatively straightforward and final establishment of a consensus in Germany that regards the Holocaust as at once historically unique and of singular paramount importance for German public memory. The construction of the Memorial for the Murdered Jews of Europe in the heart of Berlin appears to support this assumption (Müller 2001, 268-69; Niven 2002). A common implication is that a similar development must now take place at European level. A variant on this view is the suggestion by Judt that eastern European countries require their own 'Historians' Dispute,' along the lines of that experienced by West Germany in the mid 1980s (2000, 315). This argument implies incorrectly that the famous debate finally settled the thorny questions of the historical comparability, and of the relative significance for contemporary public memory, of Nazism and Communism. It overlooks the renewal of the dispute after 1989, when the earlier apparent victory of the Left was vigorously recontested by the Right. Rather revealingly, too, Judt's suggestion ignores the perspectives of those who lived under Communism, because the Historians' Dispute was a West German affair. Accounts that suggest that the same outcome - the Holocaust's historical singularity and its primacy in public memory-was achieved in the course of the 1990s are similarly problematic. They underestimate the diversity of opinion, the extent of conflict, and the fragility of the consensus that ostensibly emerged.

In fact, German debates and their outcomes were highly ambivalent. On the one hand, both in and beyond the Commissions of Inquiry, eastern dissidents and victims of Communism and western conservatives promoted the totalitarian paradigm (once again) as a quasi-official doctrine. They also sought to minimise differences between the mass crimes and the manifold forms of military and political violence in the twentieth century, and to commemorate all of their victims together. Such tendencies represented a revision of the apparent outcome of the West German Historians' Dispute, and were only in part successful (Beattie 2006). On the other hand, the recognition of the singularity of the Holocaust of European Jews, and of the need to compensate and commemorate its victims, was raised to unparalleled normative status in the course of the delegitimisation of official East German anti-fascism (and not only in that context). These apparently contradictory positions - challenging the Holocaust's singularity and 
primacy, and castigating the GDR for not acknowledging them—were sometimes advocated by the same people. In the hearing protocols and the reports of the Commissions of Inquiry one finds support both for the equation of 'red' and 'brown' regimes and the equal standing of their victims, and for the insistence on the inadmissibility of such equations (Beattie 2005a). Thus the course and result of the renewed historians' dispute was not as unambiguous as is often assumed.

Commentators who suggest that Europe could learn from the Germans in these matters often have in mind the apparently satisfactory result of German debates. They thus ignore the fact that such debates are (and must be) contested again and again. Indeed, they seem to construe, or perhaps want to draw, a 'final line' (Schlussstrich) under the old debates about whether a final line should be drawn under the past. However, the place of Nazi crimes in German public memory is subject to continual renegotiation. Its alleged primacy was challenged by adherents of totalitarianism in the 1980s, 1990s and early 2000 s, and has been repeatedly disputed by those who want more recognition of German victims of the Second World War and its immediate aftermath (Beattie 2006). The Vergegenwärtigung (recollection and making-present) of various pasts must always occur anew. Moreover, the ensuing debates are to be welcomed, rather than abhorred, if public memory is not to become irrelevant or ossify through ritualisation.

The German experiences outlined here can and should be regarded as a model for 'Europe' only to a limited extent. Yet the form of German debates - carried out as an open dispute about the interpretation and meaning of multiple pasts, at least in part in tandem and in communication with scholarly research — is worthy of imitation. Most useful in terms of content is the guiding principle that gradually established itself in German commemorative politics in the course of the 1990s, and that enjoys support across the political mainstream: 'Nazi crimes must not be relativised by the confrontation with the crimes of Stalinism. Stalinist crimes must not be trivialised through reference to the Nazi crimes' (Deutscher Bundestag 1999, I: 614). ${ }^{13}$ Disputes continue about the relative weighting of, and the degree of similarity between, the two totalitarian regimes and their macro crimes, but largely on the basis of this consensus

\footnotetext{
${ }^{13}$ Die NS-Verbrechen dürfen durch die Auseinandersetzung mit den Verbrechen des Stalinismus nicht relativiert werden. Die stalinistischen Verbrechen dürfen durch den Hinweis auf die NS-Verbrechen nicht bagatellisiert werden.
} 
(Beattie 2006). Intellectual or political complacency should not lead us either to forget that this minimal consensus was not predetermined, or to ignore that it may be challenged in the future.

The post-unification treatment of the approaches to the Nazi past of the two postwar German states is instructive here. A broad coalition strongly criticized East German anti-fascism not just for its top-down character, but also for its insufficient attention to the Holocaust. Both criticisms were justified. And yet the common conclusion that inadequate and phoney East German public memory had now to be brought into line with the laudable and authentic approach of the west was highly problematic. Some western conservative politicians and historians used the critique of the East to glorify western compensation policies, and to iron out the conflict-ridden history of the western confrontation with German guilt and responsibility. In the process, the acceptance of the Holocaust as the central event of German history was projected back into the 1950s. Conveniently forgotten in these critiques was that the key aspects of federal republican public memory, which now enjoyed normative status, had developed as recently as the 1980s or indeed the 1990s. In fact, a lack of attention to the Holocaust, and a preference for concentrating on one's own suffering or anti-Nazi resistance, had characterised not just the GDR, but also the West at least until the 1960s (Beattie 2005a).

Indeed, these characteristics were found in almost every European society for much of the postwar era, and not simply in eastern Europe into the 1990s (Lagrou 2000; Judt 2005, 804-20; Lebow et al., 2006). Recent attempts to transform the Holocaust into the EU's foundational myth thus rewrite and distort the historical record in similar (if perhaps less partisan) fashion to the efforts of German conservatives after unification. In contrast with the desire to prevent a further war among European countries, the genocide was of no significance for early western integration. That this is often overlooked from a presentist perspective contributes to a widespread sense of western superiority (Joerges 2005, 247-50; Berger N.d.). It renders 'backward' eastern Europeans who (still) utilise the totalitarian paradigm or challenge the Holocaust's uniqueness. This was evident in the interpretation of the 2004 conflict between Salomon Korn of the Central Council of Jews in Germany and the Latvian EU Commissioner Sandra Kalniete - over her insistence on the equal criminality of Communism and Nazism - as a conflict between west and east respectively (Jarausch 2004b, 4-5). In fact, 
the difference of opinion that arose exists not (only) between east and west but within each 'camp.' Like its German counterpart, the inaccurate east-west dichotomy legitimises pressure on the eastern side to conform to a seemingly unquestionable but, in fact, contested western norm (Joerges 2005, 247). In the process, it is often forgotten that the historical and symbolic foundations of the European community were, are and will continue to be, subject to change.

However problematic its backward projection may be, Holocaust memory has assumed considerable significance for the identity of many Europeans and for attempts to cultivate a European identity. For example, in 2002 the Council of Europe (2007b) decided to introduce a continent-wide Day of Remembrance, albeit with the flexibility for individual countries to select the most appropriate date. It is noteworthy that most of western and northern Europe, including Germany, commemorates the liberation of Auschwitz, other Nazi concentration camps, or the relevant country itself. Only (but not universally) in central-eastern and eastern Europe do the chosen dates bear direct relation to repression or crimes, and thus a connection to the perpetrators and not (just) the victims is created. Indeed, 'cosmopolitan memory' of the Holocaust generally focuses on the victims, and de-contextualisation, de-territorialisation and universalisation are its preconditions and consequences (Levy \& Sznaider 2002, 100-3). Instead of engaging (self-)critically with the particularities of the history of bystanders, accomplices and perpetrators in many European countries, the much sought-after common memory glides over past divisions and does not go beyond the affect of Betroffenheit (consternation). It thus militates against understanding the Holocaust's specific historical causes, course and consequences, despite the appeal of the Stockholm International Forum on the Holocaust (2001) to address precisely these dimensions. The example of the Council of Europe's Day of Remembrance should not taken to be representative of the various national public memories, but it nevertheless casts into doubt the frequently assumed German or western European entitlement and suitability to assume the role of instructor for eastern Europe or 'Europe' collectively on matters of Holocaust memory.

\section{Conclusion}

In contrast with the frequently assumed exemplary status of recent German experiences, I have argued for a more critical and nuanced understanding of unified Germany's 
handling of its complicated history. One should not be content with focusing merely on the (occasionally misrepresented) result of debates, but must also consider their inherent ambivalences and contingency. A fuller understanding, including of possible European parallels, demands consideration not only of the repeatedly renewed dispute over the appropriate place of Communism and Nazism in public memory, but also of the handling of the German division in the Cold War. Indeed, both the complex course of discussion about the precedence either of totalitarianism or of Holocaust singularity, and the highly asymmetrical handling of the postwar past, cast doubt on suggestions of a German recipe for successful integrative public memory. If any lessons can be drawn for Europe, they are not necessarily positive.

The German experience after 1990 demonstrates above all the necessity, but also the difficulty, of multiple perspectives, self-criticism and self-reflection. Only conscious efforts to minimise the political and symbolic disparities of the integration process offer the prospect of avoiding the neglect of diverse eastern (and western) experiences, memories and priorities and their assimilation with a falsely glorified western norm. Oversimplified western success stories and eastern horror stories alike are to be avoided. The European doctrine of 'unity in diversity' guarantees a degree of plurality that was lacking in the nation-state context of Germany. Nevertheless, it is essential to address differences and conflicts not only between nations, but also within them. Complexity is necessary if divergent experiences and processes in different contextslet alone their mutual interactions and interdependencies - are to be addressed. Sensitivity to historicity and contingency can also help reduce entrenched assumptions of western superiority and eastern backwardness. The projection of contemporary values and understandings of the past back into one's own history does little for one's credibility or readiness for a genuine dialogue, and reduces the past to myth. It also fails to recognise that processing, interpreting and appropriating the past never ceases, but is constantly renewed.

In Germany in the course of the 1990s it gradually became evident that east-west differences would not quickly disappear and that integration - above all of differing understandings of history — would not be 'achieved' in the immediate future (Hilsberg 1996). It was also recognised, more slowly and less universally, that this did not threaten the nation's 'inner unity' or democracy (Beattie 2007). Such lessons hardly 
need to be learnt on the European stage. Expansion and integration proceed in full consciousness of divergent, conflicting memories. Yet the asymmetries of memories and of intellectual capital remain similar. Openness to differences of opinion and possibilities for communication can always be expanded. In light of the heated debates in Germany in the early 1990s, the creation of a minimal consensus against the trivialisation of Communist crimes and the relativisation of Nazi crimes is remarkable. It was only possible in dialogue. It did not resolve every question or settle every argument. Yet it constitutes an advance precisely for that reason. Opposing perspectives may be painful or obnoxious but, in trying to learn from the 'bitter experiences' of history and overcome 'past divisions,' they are far better included and addressed than ignored or excluded. The phrases of the preamble to the EU constitution are vague and unspecific. But in so far as they recall the difficult past at all and stand in contrast to the myth of 'reunited' Europe, they are to be welcomed, particularly if they provoke debate.

\section{Reference List}

Arnswald, U. 2004, Zum Stellenwert des Themas DDR-Geschichte in den Lehrplänen der deutschen Bundesländer, Stiftung zur Aufarbeitung der SED-Diktatur, Berlin [Online]. Available: http://www.stiftung-aufarbeitung.de/dokumentation/onlinearchiv.php [accessed 28 Mar. 2007].

Bauerkämper, A., Sabrow, M., \& Stöver, B. (eds.) 1998, Doppelte Zeitgeschichte: Deutsch-deutsche Beziehungen 1945-1990, Dietz, Bonn.

Beattie, A. H. 2005a, 'Contested Legitimacy after the Cold War: The Bundestag Commissions of Inquiry into the East German Past,' PhD dissertation, The University of Sydney.

Beattie, A. H. 2005b, 'The Past in the Politics of Divided and Unified Germany,' in Partisan Histories: The Past in Contemporary Global Politics, eds. M. P. Friedman and P. Kenney, Palgrave MacMillan, New York, 17-38.

Beattie, A. H. 2006. 'The Victims of Totalitarianism and the Centrality of Nazi Genocide: Continuity and Change in German Commemorative Politics,' in Germans as Victims: Contemporary Germany and the Third Reich, ed. B. Niven, Palgrave, London, 147-63.

Beattie, A. H. 2007, 'Cold War Culture in Post-Cold War Germany: Rehabilitation and Resurrection?,' paper presented at European Cold War Cultures? Societies, Media and Cold War Experiences in East and West (1947-1990), Zentrum für Zeithistorische Forschung, Potsdam, Germany, 26-28 April.

Bender, P. 2000, “'Willkommen in Deutschland”,' in Zehn Jahre deutsche Einheit: Eine Bilanz, eds. W. Thierse, I. Spittmann-Rühle and J. L. Kuppe, Leske \& Budrich, Opladen, 13-21.

Berger, S. N.d. (in preparation), 'Remembering the Second World War, 1945-2005: Western Europe,' in The Politics of Commemoration: The Search for the Past in the Shaping of a European Culture, eds. M. Pakier and B. Stråth.

Council of Europe 2007a, History Teaching [Online]. Available: http://www.coe.int/T/E/Cultural_Cooperation/education/History\%5FTeaching/ [accessed 28 Mar. 2007].

Council of Europe 2007b, Teaching Remembrance [Online]. Available: http://www.coe.int/t/e/cultural_co-operation/education/remembrance/4.Reference\%20documents. asp\#TopOfPage [accessed 28 Mar. 2007].

Courtois, S., Werth, N., Panné, J.-L., Paczkowski, A., Bartosek, K., \& Margolin, J.-L. 1999, The Black Book of Communism: Crimes, Terror, Repression, trans. J. Murphy and M. Kramer, Harvard University Press, Cambridge, MA. 
Domnitz, C. 2007, ‘Geschichtsstunde: Europa debattiert über gemeinsames Schulbuch,’ Der Tagesspiegel, 6 March.

Deutscher Bundestag (ed.) 1995, Materialien der Enquete-Kommission 'Aufarbeitung von Geschichte und Folgen der SED-Diktatur in Deutschland' (12. Wahlperiode des Deutschen Bundestages), Suhrkamp, Frankfurt am Main.

Deutscher Bundestag (ed.) 1999, Materialien der Enquete-Kommission 'Überwindung der Folgen der SED-Diktatur im Prozess der deutschen Einheit' (13. Wahlperiode des Deutschen Bundestages), Suhrkamp, Frankfurt am Main.

European Union 2004, Treaty Establishing a Constitution for Europe [Online]. Available: http://europa.eu.int/constitution/en/ptoc1_en.htm\#a1 [accessed 29 Mar. 2007].

European Union 2007a, Celebrating Europe! $5 \overline{0}^{\text {th }}$ Anniversary of the Treaty of Rome [Online]. Available: http://europa.eu/50/index_en.htm [accessed 29 Mar. 2007].

European Union 2007b, Europa hat Geburtstag! 50. Jahrestag des Vertrags von Rom [Online]. Available: http://europa.eu/50/index_de.htm [accessed 30 Mar. 2007].

Faulenbach, B. 1999, 'Acht Jahre deutsch-deutsche Vergangenheitsdebatte: Aspekte einer kritischen Bilanz,' in Deutsche Vergangenheiten - eine gemeinsame Herausforderung: Der schwierige Umgang mit der doppelten Nachkriegsgeschichte, eds. C. Kleßmann, H. Misselwitz and G. Wichert, Christoph Links, Berlin, 15-34.

Faulenbach, B. 2006, 'Öffentliches Erinnern im vereinten Deutschland und in Osteuropa seit den 1990er Jahren,' in Instrumentalisierung, Verdrängung, Aufarbeitung: Die sowjetischen Speziallager in der gesellschaftlichen Wahrnehmung 1945 bis heute, eds. P. Haustein, A. Kaminsky, V. Knigge and B. Ritscher, Wallstein Verlag, Göttingen, 233-49.

Frei, N. 2005, 1945 und wir: Das dritte Reich im Bewußtsein der Deutschen, C. H. Beck, Munich.

Gellner, N. \& Glatzmeier, A. 2005, 'Die Suche nach der europäischen Zivilgesellschaft,' Aus Politik und Zeitgeschichte, vol. 55 , no. 36, 8-15.

Gerner, K. 1999, 'A Moveable Place with a Moveable Past: Perspectives on Central Europe,' Australian Journal of Politics and History, vol. 45, no. 1, 3-19.

Hilsberg, S. 1996, 'Die innere Einheit Deutschlands: Eine brauchbare Vision?, Deutschland Archiv, vol. 29 , no. 4, 607-12.

Hochberg, A. 1998, 'Lessons from German Unification for European Integration? A Conceptual Approach,' in East Germany's Economic Development Since Unification, eds. J. Hoscher and A. Hochberg, Palgrave Macmillan, London.

Hüttmann, J. 2004, Die 'Gelehrte DDR' und ihre Akteure: Inhalte, Motivationen, Strategien, Die DDR als Gegenstand von Lehre und Forschung an deutschen Universitäten, Institut für Hochschulforschung, Wittenberg [Online]. Available: http://www.stiftungaufarbeitung.de/downloads/pdf/hof_akteure.pdf [accessed 28 Mar. 2007].

Jarausch, K. H. 1994, The Rush to German Unity, Oxford University Press, Oxford.

Jarausch, K. H. 1995, 'Normalisierung oder Re-Nationalisierung? Zur Umdeutung der deutschen Vergangenheit,' Geschichte und Gesellschaft, vol. 21, no. 4, 571-84.

Jarausch, K. H. 2004a, “"Die Teile als Ganzes erkennen”: Zur Integration der beiden deutschen Nachkriegsgeschichten,' Zeithistorische Forschungen/Studies in Contemporary History, vol. 1, no. $1,10-30$.

Jarausch, K. H. 2004b, 'Zeitgeschichte zwischen Nation und Europa: Eine transnationale Herausforderung,' Aus Politik und Zeitgeschichte, vol. 54, no. 39, 3-10.

Jarausch, K. H. \& Lindenberger, T. (eds.) 2007, Conflicted Memories: Europeanizing Contemporary Histories, Berghahn, New York.

Joerges, C. 2005, 'Introduction to the Special Issue: Confronting Memories: European "Bitter Experiences" and the Constitutionalization Process, Constructing Europe in the Shadow of its Pasts,' German Law Journal, vol. 6, no. 2, 245-54.

Judt, T. 2000, 'The Past is Another Country: Myth and Memory in Postwar Europe,' in The Politics of Retribution in Europe: World War II and its Aftermath, eds. I. Deak, J. T. Gross and T. Judt, Princeton University Press, Princeton, 293-323.

Judt, T. 2005, Postwar: A History of Europe since 1945, Penguin, London.

Karge, H. N.d. (forthcoming), 'Practices and Politics of World War Two Remembrance: (Trans-) National Perspectives from East and Southeast Europe,' in The Politics of Commemoration: The Search for the Past in the Shaping of a European Culture, eds. M. Pakier and B. Stråth.

Kleßmann, C. 1993, 'Verflechtung und Abgrenzung: Aspekte der geteilten und zusammengehörigen deutschen Nachkriegsgeschichte,' Aus Politik und Zeitgeschichte, vol. 43, no. 29-30, 30-41.

Kleßmann, C. (ed.) 2001, The Divided Past: Rewriting Post-War German History, Berg, Oxford. 
Kleßmann, C. 2005, 'Konturen einer integrierten Nachkriegsgeschichte,' Aus Politik und Zeitgeschichte, vol. 55, no. 18-19, 3-11.

Knabe, H. 2005, Tag der Befreiung? Das Kriegsende in Ostdeutschland, Propyläen, Berlin.

Kocka, J. 1995, Vereinigungskrise: Zur Geschichte der Gegenwart, Vandenhoeck \& Ruprecht, Göttingen.

Kolář, P. 2006, 'Langsamer Abschied vom Totalitarismus-Paradigma? Neue tschechische Forschungen zur Geschichte der KPTsch-Diktatur,' Zeitschrift für Ostmitteleuropaforschung, vol. 55, no. 2, 253-75.

Lagrou, P. 2000, Legacy of Nazi Occupation: Patriotic Memory and National Recovery in Western Europe, 1945-1965, Cambridge University Press, Cambridge.

Langenbacher, E. 2003, 'Changing Memory Regimes in Contemporary Germany?, German Politics and Society, vol. 21, no. 2, 46-68.

Lebow, R. N., Kansteiner, W., \& Fogu, C. (eds.) 2006, The Politics of Memory in Postwar Europe, Duke University Press, Durham.

Levy, D., \& Sznaider, N. 2002, 'The Holocaust and the Formation of Cosmopolitan Memory,' European Journal of Social Theory, vol. 5, no. 1, 87-106.

McAdams, A. J. 1997, 'Germany after Unification: Normal at Last?,' World Politics, vol. 49, no. 2, 282308.

Meckel, M. 2001, 'Kritischer Rückblick auf die Gedenkfeiern der 10. Jahrestage von friedlicher Revolution und deutscher Vereinigung,' in Selbstbewußt in die deutsche Einheit: Rückblicke und Reflexionen, Berlin Verlag, Berlin, 219-25.

Möller, H. 1995, 'Die Relativität historischer Epochen: Das Jahr 1945 in der Perspektive des Jahres 1989,' Aus Politik und Zeitgeschichte, vol. 45, no. 18-19, 3-10.

Monteath, P. 1999, 'Contemporary Europe: Histories and Identities, Introduction,' Australian Journal of Politics and History, vol. 45, no. 1, 1-2.

Morgan, K. N.d. (in preparation), 'Neither Help nor Pardon? Communist Pasts in Western Europe,' in The Politics of Commemoration: The Search for the Past in the Shaping of a European Culture, eds. M. Pakier and B. Stråth.

Müller, J.-W. 2001, 'East Germany: Incorporation, Tainted Truth, and the Double Division,' in The Politics of Memory and Democratization: Transitional Justice in Democratizing Societies, eds. B. De Brito, C. Gonzalez Enriquez and P. Aguilar, Oxford University Press, Oxford, 248-74.

Müller, J.-W. 2007 (forthcoming), 'Thomas Manns Albtraum? Potential und Paradoxien europäischer Erinnerungspolitik,' in 'Schmerzliche Erfahrungen' der Vergangenheit und der Prozess der Konstitutionalisierung Europas, eds. C. Joerges, M. Mahlmann and U. K. Preuß, Verlag für Sozialwissenschaften, Wiesbaden.

Niethammer, L. 1999, 'Methodische Überlegungen zur deutschen Nachkriegsgeschichte: Doppelgeschichte, Nationalgeschichte oder asymmetrisch verflochtene Parallelgeschichte,' in Deutsche Vergangenheiten - eine gemeinsame Herausforderung: Der schwierige Umgang mit der doppelten Nachkriegsgeschichte, eds. C. Kleßmann, H. Misselwitz and G. Wichert, Christoph Links, Berlin, 307-27.

Niven, B. 2002, Facing the Nazi Past: United Germany and the Legacy of the Third Reich, Routledge, London.

Oswald, F. 2004, 'Negotiating Identities: The Party of Democratic Socialism between East German Regionalism, German National Identity and European Integration,' Australian Journal of Politics and History, vol. 50, no. 1, 75-85.

Parliamentary Assembly of the Council of Europe, 2006, Resolution 1481: 'Need for International Condemnation of Crimes of Totalitarian Communist Regimes.' [Online]. Available: http://assembly.coe.int/Main.asp?link=/Documents/AdoptedText/ta06/ERES1481.htm [accessed 13 Mar. 2007].

Pasternack, P. 2001, Gelehrte DDR: Die DDR als Gegenstand der Lehre an deutschen Universitäten 1990-2000, Institut für Hochschulforschung, Wittenberg [Online]. Available: http://www.stiftungaufarbeitung.de/dokumentation/onlinearchiv.php [accessed 28 Mar. 2007].

Pavković, A. 2000, 'Constructing a European Identity: Problems of Supranationalism,' in Why Europe? Problems of Culture and Identity, eds. J. Andrew, E. Kolinsky and M. Waller, Macmillan, London, 115-30.

Pingel, F. 2000, The European Home: Representations of 20th Century Europe in History Textbooks, Council of Europe, Strasbourg.

Pratt, M. 2005, 'Imagining Union: European Cultural Identity in the Pre-Federal Future Perfect,' Portal Journal of Multidisciplinary International Studies, vol. 2, no. 2 [Online]. Available: http://epress.lib.uts.edu.au/ojs/index.php/portal/article/view/110/69 [accessed 13 Mar. 2007]. 
Rousso, H. 2004, 'Das Dilemma eines europäischen Gedächtnisses,' Zeithistorische Forschungen/Studies in Contemporary History, vol. 1, no. 3 [Online]. Available: http://www.zeithistorischeforschungen.de/site/40208268/default.aspx [accessed 13 Mar. 2007].

Schildt, A. 1999, Ankunft im Westen: Ein Essay zur Erfolgsgeschichte der Bundesrepublik, S. Fischer, Frankfurt am Main.

Sinn, H. W. 2000, 'EU Enlargement, Migration, and Lessons from German Unification,' German Economic Review, vol. 1, no. 3, 299-314.

Speth, R. 1999, 'Europäische Geschichtsbilder heute,' in Umkämpfte Vergangenheit: Geschichtsbilder, Erinnerung und Vergangenheitspolitik im internationalen Vergleich, eds. P. Bock and E. Wolfrum, Vandenhoeck \& Ruprecht, Göttingen, 159-75.

Stockholm International Forum on the Holocaust, 2001, Declaration of the Stockholm International Forum on the Holocaust [Online]. Available: http://www.holocaustforum.gov.se/pdfandforms/deklarat..pdf [accessed 13 Mar. 2007].

Stradling, R. 2003, Multiperspectivity in History Teaching: A Guide for Teachers, Council of Europe, Strasbourg.

Thum, G. 2004, “"Europa” in Ostblock: Weiße Flecken in der Geschichte der europäischen Integration,' Zeithistorische Forschungen/Studies in Contemporary History, vol. 1, no. 3 [Online]. Available: http://www.zeithistorische-forschungen.de/site/40208270/default.aspx [accessed 30 Mar. 2007].

Troebst, S. 2006, 'Am Anfang des GULag-Gedächtnisses: Das Jahr 1956 und Europas aktuelle Erinnerungskonflikte,' Deutschland Archiv, vol. 39, no. 1, 19-26.

Vertrag zwischen der Bundesrepublik Deutschland und der Deutschen Demokratischen Republik über die Herstellung der Einheit Deutschlands, 1990 [Online]. Available: http://www.jura.unisb.de/Vertraege/Einheit/ein1_e.htm [accessed 13 Mar. 2007].

Vike-Freiberga, V. 2005, Declaration by H.E. Dr. Vaira Vike-Freiberga, President of the Republic of Latvia regarding 9 May 2005, Riga, 12 January [Online]. Available: http://www.am.gov.lv/en/news/speeches/2005/January/12-1/ [accessed 13 Mar. 2007].

Weitz, E. D. 2001, 'The Ever-Present Other: Communism in the Making of West Germany,' in The Miracle Years: A Cultural History of West Germany, 1949-1968, ed. H. Schissler, Princeton University Press, Princeton, 219-32.

Wüstenberg, R. K. 2004, Die politische Dimension der Versöhnung: Eine theologische Studie zum Umgang mit Schuld nach den Systemumbrüchen in Südafrika und Deutschland, Gütersloher Verlagshaus, Gütersloh.

Zens, M. 2000, 'Truism and Taboo: The Rhetoric of the Berlin Republic,' in Political Thought and German Reunification: The New German Ideology, eds. H. Williams, C. Wight and N. Kapferer, Macmillan, Basingstoke, 64-95. 